\title{
THE ESCHATOLOGICAL INTERDEPENDENCE OF JEWS AND GENTILES IN GALATIANS
}

\author{
John W. Taylor
}

\begin{abstract}
Summary
Agitators in Galatia insisted that law observance for Gentiles was essential, because the eschatological blessing promised to the heirs of Abraham is only to be found within Israel. But in three key passages (3:13-14; 3:25-26; 4:4-7), which are frequently misunderstood because pronominal shifts are set aside, Paul makes the blessing of Jews and Gentiles in Christ mutually interdependent, in a theological sense. Gentiles are blessed with the blessing of Abraham because Jews are set free by Christ from the curse of the law. Because the Gentiles are blessed, and have become sons of God, Jewish believers receive the Spirit. Thus Gentile inclusion in Christ is not subsidiary to Israel's eschatological status, and does not require law observance.
\end{abstract}

\section{Introduction}

Three key passages in Galatians have unexpected changes in person (Gal. 3:13-14; 3:25-26; 4:4-7). Paul's changes from 'we' to 'you' and back again - between first and second person plurals - have rarely appeared important to his theology, on the assumption that they derive from his epistolary practice of including his readers within the scope of his rhetoric. A fresh reading of these passages suggests that these changes, which seem to be somewhat awkward grammatical shifts, have an identifiable pattern, and signify an unexpected but substantive point.

Paul is countering the theology of agitators who insist that, in order to be justified, Gentile converts to Christ must be circumcised and come under the law. According to the agitators, Gentile inclusion is only within the law, and thus subsidiary to God's blessing of Israel. 
Those under the law of Moses have a privileged status before God, which is only available to Gentile believers if they become proselytes to Judaism. Paul insists in contrast that Jew and Gentile have equal standing in Christ (3:28). In regard to being in Christ-in the new creation - the categories of Jew and Gentile have no meaning (6:15). But in the passages under review in this paper, he goes one step further. Paul's interpretation of the Abrahamic covenant makes the eschatological blessing of Jews and Gentiles mutually necessary and interdependent. One will not happen without the other.

The idea that the blessing of Gentiles would result from the eschatological fulfilment of divine promises to Israel is common both in Old Testament prophetic literature and in Second Temple writings, even though the precise nature of the resulting status or the requirements made upon Gentiles varies. ${ }^{1}$ Paul has a similar view, though it is christologically defined: Gentiles are blessed in Abraham: 'In you all the Gentiles will be blessed' (Gal. 3:8; cf. Gen. 12:3; 18:18). ${ }^{2}$ They are blessed when they share the faith of Abraham (Gal. 3:9). They receive the Abrahamic blessing in the Messiah, Jesus (3:13). They receive it also because Jews have been set free by Christ from the curse of the law (3:13-14).

Even more strikingly, though largely overlooked in studies of Galatians, Jewish believers receive the Spirit because of this same blessing of the Gentiles $(3: 13-14 ; 4: 6)$. Thus Gentile inclusion in Christ, Paul claims, far from being subsidiary or secondary, is necessary for the full eschatological blessing of Jews. It should be emphasised that in Galatians this dependency is logical and theological, rather than historical or missiological.

1 Gen. 12:1-3; Ps. 22:27; 67:1-2; 98:1-3; 102:13-16; 117; Isa. 42:1-12; 45:14-25; 49:6; 52:8-10; 59:19-20; 60:1-3; 60-62; 66:19-21; Jer. 16:14-19; Ezek. 37:21-28; Amos 9:11-12; Mic. 4:1-8; Zech. 2:1-11; Pss. Sol. 17:21-32; Tg. Onq. Gen. 49:10; Tob. 13:9-11; 1 Enoch 48:4; T. Lev. 4:4; T. Ben. 9:2, 10:5. See James M. Scott, “"For as Many as Are of Works of the Law Are under a Curse" (Galatians 3.10)' in Paul and the Scriptures of Israel, ed. Craig A. Evans and James A. Sanders (Sheffield: JSOT Press, 1993): 187-221, esp. 212; John W. Taylor, 'From Faith to Faith: Romans 1.17 in the Light of Greek Idiom', NTS 50 (2004): 337-48, esp. 345.

2 Translations are the work of the author unless otherwise indicated. 
Important parallels between $3: 13-14$ and $4: 4-7^{3}$ point to an underlying eschatological framework by which Paul can make these bold claims. ${ }^{4}$ Both passages are set in the context of eschatological fulfilment. The blessing of the Gentiles $(3: 6-9,14)$, which Paul sees occurring as a fulfilment of the foreknowledge and prior proclamation of Scripture (3:8), frames the discussion of the curse of the law in 3:1013, while according to $4: 4$, God sent his Son 'when the fullness of time came'. ${ }^{5}$ Both passages declare that Christ has redeemed Jews in regard

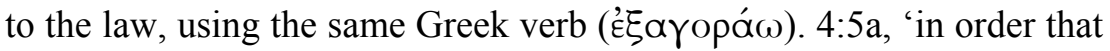
he might redeem those under the law', ${ }^{6}$ is, with minor differences of emphasis, ${ }^{7}$ a repeat of 3:13a, 'Christ redeemed us from the curse of the law'. Both passages then turn to the eschatological blessing of the Gentiles. In 3:14, as a result of the redemption of Jews from the curse of the law, the blessing of Abraham comes to the Gentiles in Christ Jesus. In 4:6 Paul, after recognising the redemption and adoption

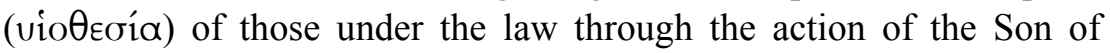
God, declares that 'you are sons'; the second person plural દ́oté ('you are') refers to the Gentile Galatians. Both passages then describe the reception of the Spirit by Jewish believers as a result of the new eschatological status of the Gentiles. In 3:14, the blessing of the Gentiles in Christ Jesus happens 'in order that we [Jews] might receive the promise of the Spirit through faith'. In 4:6, Paul says that because

3 Some of the parallels between these passages have been noted previously. See Terence L. Donaldson, "The "Curse of the Law" and the Inclusion of the Gentiles', NTS 32 (1986): 94-112, esp. 95; In-Gyu Hong, The Law in Galatians (JSNTSup, 81; Sheffield: JSOT Press, 1993): 78-79.

4 The idea of an underlying narrative shaping the presentation of Paul's thought in Galatians can be attributed to Richard B. Hays, The Faith of Jesus Christ: An Investigation of the Narrative Substructure of Galatians 3:1-4:11 (2nd edn; Grand Rapids: Eerdmans, 2002).

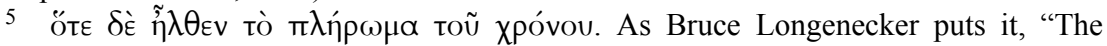
context is wholly eschatological" (Bruce W. Longenecker, The Triumph of Abraham's God: The Transformation of Identity in Galatians [Edinburgh: T\&T Clark, 1998]: 60);

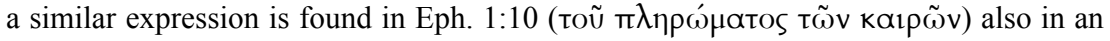
eschatological context which concerns Christ and the inheritance.

6 It is possible that 'under the law' (úmò vó $\mu$ ov) in 4:5 is an abbreviated reference to 'under the curse of the law' (Todd A. Wilson, The Curse of the Law and the Crisis in Galatia: Reassessing the Purpose of Galatians [WUNT, 2/225; Tübingen: Mohr Siebeck, 2007]: 31-34).

7 They differ in that the emphasis in 3:13 is on the curse of the law by contrast to the blessing of Abraham, while in 4:5, following immediately upon the analogy of growing up under administrators and stewards (4:2) and Paul's description of Christ as 'born under the law' ( $\gamma$ Evó $\mu \varepsilon v o v$ úrò vó $\mu$ ov, 4:4), the emphasis is on release from the mastery of the law. 
the Galatians are sons of God, 'God sent the Spirit of his Son into our hearts', a further reference to Jewish reception of the Spirit. ${ }^{8}$ The framework that Paul lays out can be represented thus:

Christ's redemption of Jews from the curse of the law $\rightarrow$

The blessing of the Gentiles: sonship

The blessing of the Jews: reception of the Spirit.

Parallels between these two passages and Galatians 3:25-26, not often recognised by commentators, strengthen this reading. First, this passage also is set in the context of eschatological fulfilment. The law's role as Israel's custodian lasted only until the coming of faith (3:23$25)$. Now the promises are being fulfilled $(3: 22,29)$, and the effective rule of the Mosaic Law is coming to an end. Second, there is a setting free from the power of the law, which has heretofore guarded Israel in what might be called protective custody, but which was to Paul nevertheless an imprisonment (Gal. 3:23-24). Unlike the other two passages, there is no mention of redemption, but that is because the analogy is different, explicating neither a redemption from the curse of the law (3:13), nor one from slavery under the law (4:5-7), but the end of the rule of the law as custodian ( $\pi \alpha 1 \delta \alpha \gamma \omega \gamma$ ós). Third, Paul also mentions the eschatological blessing of the Gentiles. As in 3:14, this blessing occurs 'in Christ Jesus', though there is no mention of the Spirit.

All three passages are followed immediately by a discussion of inheritance. Paul's ultimate interest is in showing that the Gentiles, in Christ and without the law, are indeed heirs of the kingdom of God. ${ }^{9}$ In 3:15-18, Paul shows that Abraham's inheritance is received through promise, not law, and that the promises were made to Abraham's singular seed, Christ. In 3:26-29, Paul shows that the sole qualification for inheriting the promises to Abraham is to be Abraham's seed, and this happens in Christ and by faith. In 4:7, Paul returns from his discussion of the status of Jews to that of his largely Gentile readers. They are no longer slaves, but sons, and thus heirs 'through God'. ${ }^{10}$

8 That Jewish believers are in view in 3:14 and 4:6 will be addressed further below.

9 Gal. 4:30, 5:21. See Yon-Gyong Kwon, Eschatology in Galatians: Rethinking Paul's Response to the Crisis in Galatia (WUNT, 183; Tübingen: Mohr Siebeck, 2004): 125-27.

10 Here Paul addresses his readers in the second person singular. This is most likely intended to personalise or individualise what has so far been expressed in corporate or communal terms. 
These parallels indicate that the three passages concerned can and should be read together. A closer examination of all three key passages will help establish their witness to Paul's view that the eschatological blessing of Jews and Gentiles in Christ was interdependent.

\section{Galatians 3:13-14}

For the purposes of this investigation, there are three major issues in this passage: (1) What is the referent of 'us' ( $\dot{\eta} \mu \tilde{\alpha} \varsigma)$ in $3: 13$ ? Who is it that Christ redeemed from the curse of the law? (2) Whether the two purpose clauses in 3:14 are sequential or co-ordinate? To put it another way, are they operating in parallel or in series? How does the reception of the Spirit relate to the blessing of the Gentiles? (3) What is the subject of the verb 'receive' ( $\lambda \alpha \dot{\beta} \omega \mu \varepsilon v)$ in 3:14? To whom does the promise of the Spirit apply?

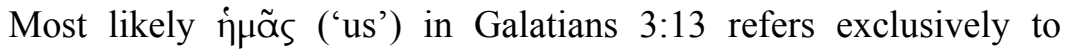
Jewish believers in Christ, not inclusively to all believers. ${ }^{11}$ It stands to reason that those who are the subject of the curse which the law pronounces (3:10) are also the subject of the redemption from 'the curse of the law' in 3:13.12 But what is the identity of those who are 'of

11 Eckstein argues for inclusivity because the broader context indicates that both Jews and Gentiles receive justification and the Spirit in Christ, but he can do this only by reducing the pronominal shifts in 3:13-14 to meaninglessness (Hans-Joachim Eckstein, Verheißung und Gesetz: Eine exegetische Untersuchung zu Galater 2,15-4,7 (WUNT, 86; Tübingen: Mohr Siebeck, 1996): 151-52). For an inclusive view see also Heinrich Schlier, Der Brief an die Galater (15th edn; KEK, 7; Göttingen: Vandenhoeck \& Ruprecht, 1989): 137; David Brondos, 'The Cross and the Curse: Galatians 3.13 and Paul's Doctrine of Redemption', JSNT 81 (2001): 3-32, esp. 23 n. 72; Richard N. Longenecker, Galatians (WBC, 41; Dallas: Word Books, 1990): 121. Longenecker argues that Paul has in mind 'those under the law' but 'refers to Gentiles who [have] not yet submitted to circumcision'. An exclusive view is held by many scholars, including Michael Bachmann, Antijudaismus im Galaterbrief?: Exegetische Studien zu einem polemischen Schreiben und zur Theologie des Apostels Paulus (Novum Testamentum et Orbis Antiquus, 40; Göttingen: Vandenhoeck \& Ruprecht, 1999): 187; Hans Dieter Betz, Galatians: A Commentary on Paul's Letter to the Churches in Galatia (Hermeneia, Philadelphia: Fortress Press, 1979): 148; Donaldson, 'Curse', 98; George S. Duncan, The Epistle of Paul to the Galatians (MNTC; New York: Harper, 1934): 99; Jan Lambrecht, Pauline Studies: Collected Essays (Bibliotheca Ephemeridum Theologicarum Lovaniensium, 115; Leuven, Belgium: Peeters, 1994): 287; B. Longenecker, Triumph, 92.

12 Witherington notes 'the emphatic placement of $\eta \mu \tilde{\alpha} \varsigma$ ' in $3: 13$, by contrast to the forward placement of ' $\bullet \theta v \eta$ in 3:14 (Ben Witherington, Grace in Galatia: A Commentary on St Paul's letter to the Galatians [Grand Rapids: Eerdmans, 1998]: 237). 


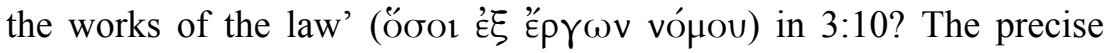

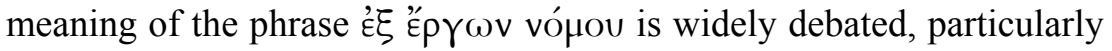
in the light of Dunn's suggestion that 'works of the law' in Paul refers primarily to those aspects of the law, such as circumcision, which distinguish Jews from the surrounding cultures. ${ }^{13}$ Some translations

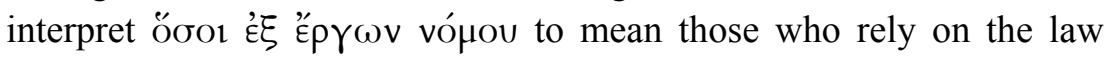
(ESV, NIV, NRSV), suggesting a negative connotation of legalism, but this is an unwarranted conclusion here. To use the language of reliance is to import something into the text which is not justified by the Greek preposition, case or vocabulary. The phrase is more likely simply a descriptor for those within Judaism. The parallel phrase in 3:7 and 3:9,

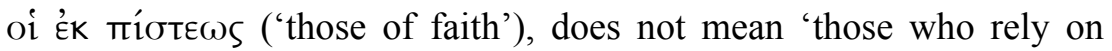
faith', ${ }^{14}$ which would be a tautology, but rather those who have faith, or

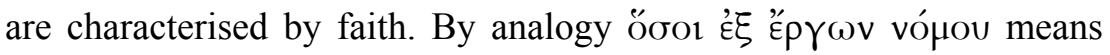
'those who are characterised by the practice of the law'. ${ }^{15}$ Those who are 'of the works of the law' are those who are under the law, and defined according to their common adherence to the law. That is, they are Jews, viewed from the perspective of their relationship to the law. Paul is one of them. By implication the description would apply also to the Galatian Gentile believers should they choose to proselytise to Judaism. ${ }^{16}$

All those who are 'of the works of the law' are cursed, and this, Paul declares, citing Deuteronomy 27:26, is because they do not do everything written in the book of the law. In saying this Paul shares the deuteronomistic and prophetic critique of Israel which pronounces a

13 James D. G. Dunn, 'The New Perspective on Paul' in Jesus, Paul, and the Law: Studies in Mark and Galatians (Louisville: Westminster/John Knox, 1990): 183-214, esp. 194; repr. from BJRL 65.2 (1983): 95-122. He narrows the definition of óoor $\mathfrak{\varepsilon} \xi$ "E $p$ $\omega v$ vópou to those who were 'putting too much weight on the distinctiveness of Jews' (James D. G. Dunn, The Epistle to the Galatians [BNTC; Peabody, Massachusetts: Hendrickson, 1993]: 171). Dunn later acknowledges that 'works of the law' refers to 'whatever the law requires' but insists that 'in a context where the relationship of Israel to other nations is at issue, certain laws would naturally come in to focus more than others' (The Theology of Paul the Apostle [Grand Rapids: Eerdmans, 1998): 358).

14 Contra Longenecker, Galatians, 166.

15 Attempts to narrow the definition to the troublemakers (Jeffrey R. Wisdom, Blessing for the Nations and the Curse of the Law: Paul's Citation of Genesis and Deuteronomy in Gal. 3.8-10 [WUNT, 2/133; Tübingen: Mohr Siebeck, 2001]: 156-68) miss the larger contrast being drawn between faith and works of the law.

16 See Betz, Galatians, 144; Frank Thielman, Paul and the Law: A Contextual Approach (Downers Grove: InterVarsity, 1994): 126. 
curse upon Israel's disobedience to the law (Deut. 28:15; 29:24-28; Jer. 11:1-5; Dan. 9:11). ${ }^{17}$ The law curses those it addresses. Scholars disagree as to whether there is an underlying assumption of Israel's inability to keep the whole law, ${ }^{18}$ but there is at least an assumption in Galatians 3:10 that Israel has not in fact kept the law. ${ }^{19}$

It has been argued that the reference to Christ becoming a curse 'for us' (ưrè because $\dot{u} \pi \dot{\rho} \rho \dot{\eta} \mu \tilde{\omega} v$ 'is a common catechetical and liturgical formula' for the early church. ${ }^{20}$ However, it is unlikely that such a short prepositional phrase would only be used for inclusive catechetical formulae; Paul himself uses it in non-formulaic contexts (2 Cor. 1:11; 5:12; 7:12; Rom. 8:34) as well as formulaic (Rom. 5:8; 8:31; 2 Cor. 5:21; 1 Thess. 5:10), and on one occasion (Rom. 8:32) qualifies it with the inclusive adjective $\pi \alpha v \tau \tilde{\omega} v$ : 'For us all'. There is no reason to suppose that Paul could not make use of it with particular application to Jews. Some of those who were 'of the works of the law', are now 'of faith' $(3: 9,14)$. It is this group - and the first person plural means that Paul includes himself among them - that Christ has redeemed from the curse of the law. Consequently the redemption of Jews (3:13) is

17 'Deuteronomy 27:26 summarises a prominent theme throughout Deuteronomy and $\ldots$ in the Bible generally: Israel stands cursed by the law if it disobeys the law, and Israel will not obey it (or has not obeyed it)' (Thielman, A Contextual Approach, 126). 18 The traditional view is that Paul implies an inability. See Jean Calvin, Commentaries on the Epistles of Paul to the Galatians and Ephesians (Grand Rapids: Eerdmans, 1957): 89; J. B. Lightfoot, St. Paul's Epistle to the Galatians: A Revised Text with Introduction, Notes, and Dissertations (London: Macmillan, 1876): 137; Udo Borse, Der Brief an die Galater (Regensburg: F. Pustet, 1984): 74; Heikki Räisänen, Paul and the Law (WUNT 29; Tübingen: J. C. B. Mohr, 1983): 94; Thomas R. Schreiner, 'Is Perfect Obedience to the Law Possible? A Re-examination of Galatians 3:10', JETS 27 (1984): 151-60; Francis Watson, Paul, Judaism and the Gentiles: A Sociological Approach (SNTSMS, 56; Cambridge: Cambridge University Press, 1986): 71; R. Barry Matlock, 'Helping Paul's Argument Work? The Curse of Galatians 3.1014' in Torah in the New Testament, ed. Michael Tait and Peter Oakes (London: T\&T Clark, 2009): 154-79. This view has been attacked by Sanders as overemphasising mãoıv ('every') in the quotation from Deut. 27:26, relying on an unstated assumption of inability, underplaying the context which makes $3: 10-13$ subsidiary to $3: 8$ as proof that the Gentiles are justified (or 'righteoused') by faith, and ignoring the law's provision of atonement for those who disobey (E. P. Sanders, Paul, the Law and the Jewish People (Minneapolis: Fortress, 1983): 20-23, 28).

19 See Thielman, A Contextual Approach, 127; N. T. Wright, The Climax of the Covenant: Christ and the Law in Pauline Theology (Minneapolis: Fortress, 1993): 14448.

20 G. Walter Hansen, Abraham in Galatians: Epistolary and Rhetorical Contexts (JSNTSup, 29; Sheffield: JSOT Press, 1988): 123. See Lambrecht, Pauline Studies: Collected Essays, 286. 
according to Paul the necessary 'precondition for the blessing of the Gentiles'. ${ }^{21}$

The next question is whether the two clauses starting with iva ('so that') in 3:14 are co-ordinate or sequential. If they are co-ordinate, the blessing of the Gentiles (3:14a) and the reception of the promised Spirit (3:14b) are two distinct results of the redemption of Israel from the curse of the law. If they are sequential, which is to say that the second clause is dependent on the first, then the reception of the Spirit $(3: 14 \mathrm{~b})$ can be seen as the result of the blessing of the Gentiles in Christ (3:14a). Here the commentators are mostly on the side of parallelism. ${ }^{22}$

Some suggest that the two are co-ordinate because both refer to events which can be said to be the result of Christ's redemptive sacrifice. ${ }^{23}$ While both elements can be seen in this way, it does not obviate the possibility of secondary causation in Paul's argument, or that Paul is using the clauses in sequence, particularly if Israel is the focus of the redemption mentioned in 3:13. Even if for Paul the blessing of Abraham coming to the Gentiles, and the Jewish (or universal) reception of the promise of the Spirit both ultimately result from the cross, in Christ and through faith, it does not mean that the two clauses are grammatically parallel. There already is another grammatical shift in the second clause, with focus moving from the third-person (Gentiles) to the first-person (Jews).

Some hold to the clauses as a pair of statements summarising the argument starting in $3: 1$. Sanders sees a chiasm whereby $3: 14 \mathrm{~b}$ repeats the point made in $3: 1-5$, and $3: 14 \mathrm{a}$ the point made in $3: 8 .{ }^{24}$ In Christ, and by faith, rather than by works of the law, the Gentiles are blessed and the Spirit is received. The problem, though, with theories that make $3: 14 \mathrm{~b}$ the recapitulation of $3: 2$ is that they ignore the shifts in subject:

21 Donaldson, 'Curse', esp. 98. See also Wright, Climax of the Covenant, 142-43.

22 Duncan calls them 'strictly coordinate' (Duncan, Galatians, 103). See also C. J. Ellicott, St. Paul's Epistle to the Galatians (4th edn; London: Longmans, Green, 1867): 75; Franz Mußner, Der Galaterbrief: Auslegung (HKNT, 9; Freiburg: Herder, 1988): 235; Longenecker, Galatians, 14.

23 F. F. Bruce, The Epistle of Paul to the Galatians: A Commentary on the Greek Text (NIGTC; Grand Rapids: Eerdmans, 1982): 167; Ernest De Witt Burton, A Critical and Exegetical Commentary on the Epistle to the Galatians (ICC; New York: Charles Scribner's Sons, 1920): 176; Dunn, Galatians, 179; Kwon, Eschatology, 107, D. F. Tolmie, Persuading the Galatians: A Text-Centred Rhetorical Analysis of a Pauline Letter (WUNT, 2/190; Tübingen: Mohr Siebeck, 2005): 122.

24 Sanders, Jewish People, 22; See also Tolmie, Persuading the Galatians, 122. 
'you' in 3:1-5, 'we' in 3:13-14.25 The emphasis in 3:1-8 is on the experience of the Gentiles quite apart from works of the law, but from $3: 10-13$ it is on the experience of Jews, in relation to the works of the law, with 3:9 transitional. Williams suggests that the 'blessing of Abraham' is justification, and thus the clauses 3:14a and 3:14b represent the intertwined 'categories of justification and receiving the Spirit', which imply each other, even though they are conceptually distinct. He sees the shift in pronouns as simply for emphasis. ${ }^{26}$ However, though thematically the two clauses pick up ideas discussed

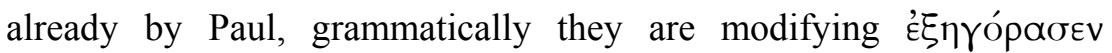
('redeemed') in 3:13, and thus they must be explained in terms of the redemption of Israel from the curse of the law, not detached from the sentence they are located in.

Some authors hold that while the clauses are grammatically coordinate the second clause is in some sense presupposed by the first. ${ }^{27}$ But the idea that the clauses are strictly in sequence, if it is mentioned at all, is dismissed as 'difficult' ${ }^{28}$ mostly it is not even considered. However, there are strong reasons to allow for the possibility of sequential clauses in Galatians 3:14 (and 4:5), both in regard to grammar and in regard to context and concept.

An examination of all instances in Paul of consecutive clauses starting with iva ('so that'), which could both indicate purpose or result, and are not connected by another conjunction defining their relationship, reveals not a single instance where those clauses are conclusively co-ordinate. Of the thirteen such constructions in the Pauline letters, ${ }^{29}$ only five instances are sometimes thought to be coordinate purpose clauses. Two (Gal. 3:14 and 4:5) are the subject of particular discussion in this paper and will be examined further below.

25 Cf. Wisdom, Blessing for the Nations, 198.

26 Sam K. Williams, 'Justification and the Spirit in Galatians', JSNT 29 (1987): 91100, esp. 97).

27 Thus for Borse, 'Der zweite setzt das Geschehen des ersteren voraus und ist ihm parallel zugeordnet' ('The second presupposes the event of the first and is co-ordinated parallel to it'. Borse, An die Galater, 130, italics added). Lightfoot marginally favours the 'moral dependence' of the second on the first from the perspective of the order of salvation (Lightfoot, Galatians, 140). See also Betz, Galatians, 152; Gordon D. Fee, God's Empowering Presence: The Holy Spirit in the Letters of Paul (Peabody: Hendrickson, 1994): 393.

28 Burton, Epistle to the Galatians, 176.

29 Rom. 7:13; 15:31-32; 1 Cor. 4:6; 7:5; 2 Cor. 9:3; 12:7; Gal. 3:14; 4:5, Eph. 5:2527; 6:19-20; Phil. 1:9-10; Col. 4:3-4; Titus 2:4-5. 
The others are Romans 7:13, 2 Corinthians 9:3 and Ephesians 6:19$20 .{ }^{30}$

The two clauses in Ephesians 6:19-20 have occasionally been read as co-ordinate purpose clauses, but it is more likely that the first clause is not a purpose clause at all but a noun clause indicating the content of a prayer request. The second shows the purpose or result of that prayer. Paul asks for prayer for 'utterance' ( $\lambda$ ó Yoऽ) so that he can proclaim the gospel boldly. The same can be said about the parallel in Colossians 4:3-4, and the similar prayer request in Romans 15:31-32. Philippians 1:9-10 is a prayer, not a prayer request, but follows the same pattern. Thus we can identify a prayer formula, consisting not of parallel purpose clauses, but of a content clause followed by a purpose clause, each starting with ivo.

In Romans 7:13 there is obvious ellipsis, and the two clauses have parallel elements, but nevertheless the second clause is clearly dependent on the first. It was not the law that brought death but sin, 'in order that [iva] sin might be manifest, working death in me through that which is good, in order that [iva] sin might become surpassingly sinful through the commandment'. That is, sin becomes exceedingly sinful because it works death through the commandment. It is also possible to see the second clause as a noun clause, epexegetical to the first, restating it in vivid terms; Käsemann denies that the clauses are sequential but then says, 'The second discloses in rhetorical crescendo the point of the first'. ${ }^{31}$ This interpretation is expressed in the ERV translation: 'But sin, that it might be shewn to be sin, by working death to me through that which is good; - that through the commandment sin might become exceeding sinful' ${ }^{32}$ In 2 Corinthians 9:3 also, the second iva clause does not indicate purpose but is a noun clause stating the content of the boast mentioned in the first, as is confirmed by the way

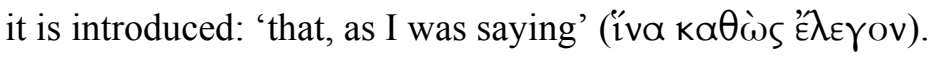

There are five examples in the Pauline corpus which do contain sequential purpose clauses, where both are introduced by iva: in 1 Corinthians 4:6 the purpose of the Corinthians learning not to go beyond what is written, is that they will not be puffed up against one another. In 1 Corinthians 7:5 the purpose of married couples only

\footnotetext{
30 See Burton, Epistle to the Galatians, 75.

31 Ernst Käsemann, Commentary on Romans (Grand Rapids: Eerdmans, 1980): 198.

32 The ESV reads the clauses as co-ordinate, adding the conjunction 'and' between them.
} 
depriving each other for a limited and agreed time is that they will not be tempted by Satan beyond what they can bear. In 2 Corinthians 12:7

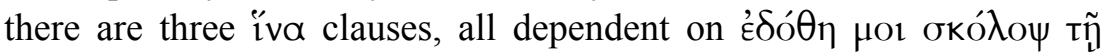
барк1 ('a thorn in the flesh was given to me'). The first and the third

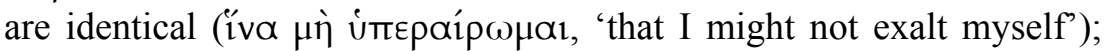
the third simply repeats what was said already. The second and the third are in consecutive relationship: 'a thorn in the flesh was given to me, an angel of Satan, so that I might be buffeted, so that I might not exalt myself'. In Ephesians 5:25-27, the purpose (or result) of Christ's loving the church and giving himself for her, is that, having washed her, he might sanctify her. The purpose of the sanctification is that he might present the church to himself in glory. ${ }^{33}$ In Titus 2:4-5, the purpose of older women advising the younger on how to conduct themselves, is that the 'the word of God might not be reviled'. Thus when Paul uses two consecutive purpose clauses, each starting with ivo, without joining them with another conjunction, the second clause is invariably subordinate to and dependent on the first. Furthermore, the pattern holds true elsewhere in the New Testament. ${ }^{34}$

There are also eleven instances where Paul has two parallel subjunctive verbs indicating purpose, both dependent on a single subordinating ivo ('so that'), and connected with a co-ordinating conjunction such as kái ('and') or à $\lambda \lambda \alpha$ ' ('but'). ${ }^{35}$ This appears to be his preferred construction when wanting to use subjunctive verbs of purpose in parallel, supporting the likelihood that the clauses in 3:14 and $4: 5$ are not co-ordinate.

Several authors claim that the promise of the Spirit in 3:14b simply provides the content of the blessing given to the Gentiles in 3:14a. That is, they are reading the first clause as showing purpose, and the second as noun clause, epexegetical to it. From this point of view, 'the blessing

33 The third iva clause in the passage is introduced by the conjunction 'o $\lambda \lambda \alpha$ ' ('but'): 'but that she might be holy and blameless'.

34 John $1: 7 ; 15: 16 ; 17: 21,23,24$. In John 15:16 the first clause contains two coordinate subjunctive verbs of purpose joined by kaí ('and'), both dependent on the first iva. The second iva clause is consecutive, indicating the purpose or result of the first; the first clause shows the condition of the second: going and bearing abiding fruit leads to answered prayer. In Mark 5:23 the first clause is probably a noun clause. In Mark 3:14 two iva purposes clauses are co-ordinate, but are joined by the conjunction kaí ('and').

35 Rom. 3:19; 15:31; 16:2 (where the two subjunctive verbs may also be understood as imperatival), 1 Cor. 7:5; 12:25; 14:31; 2 Cor. 9:5; Phil. 2:10-11; 2:28; 3:8-9; Col. 4:8; 1 Thess. 4:12. 
of Abraham' is further defined as the reception of the promised Spirit. ${ }^{36}$

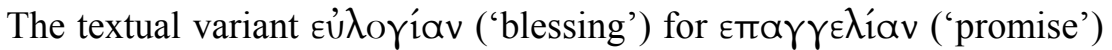
in several manuscripts ( $\mathfrak{P}^{46} \mathrm{D} \mathrm{F} \mathrm{G}$ ), by way of assimilation to $3: 14 \mathrm{a}$, may represent early testimony to this interpretation. ${ }^{37}$ Paul has already reminded the Galatians that they have received the Spirit 'by the hearing of faith' $(3: 2,5)$. He follows this reminder with a comparison: ${ }^{38}$ 'So then, he who supplies you the Spirit and works miracles among you; is it by works of the law or by the hearing of faith?-just as

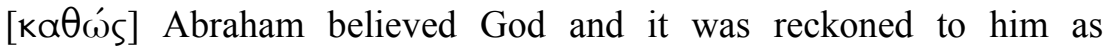
righteousness' (3:5-6). But it would be a mistake to identify precisely the promise of justification by faith with the promise of the Spirit, even though the two are closely linked aspects of Pauline soteriology. The comparison Paul makes in 3:5-6 is to equate the faith of Abraham with the faith of the Gentiles. He argues that believers are the sons of Abraham (3:7), and he identifies the blessing of Abraham, which the Gentiles were to receive, as justification by faith: 'And the Scripture, foreseeing that God would justify the Gentiles by faith, preached the gospel in advance to Abraham; 'In you shall all the nations be blessed' $(3: 8) .{ }^{39}$ It is better then to see the reception of the Spirit in Paul not as defining the blessing of Abraham, but as one aspect of it. But in 3:14a, in view of 3:6-9, the emphasis is surely on justification by faith as the blessing of Abraham.

Further, if the clauses are simply co-ordinate, or if the second clause is a noun clause, so that, in either case, the blessing of the Gentiles is to be identified contiguously with 'our' reception of the Spirit, why should Paul change the focus from third to first person in the second clause? Since it is the Gentiles who are the object of the blessing in $3: 14 \mathrm{a}$, then in that case the promise of the Spirit here would only apply

36 Thus for Schlier, 'Der Segen Abrahams wird als Geist interpretiert' ('The blessing of Abraham is interpreted as Spirit' (italics mine), Schlier, An die Galater, 141). See also Betz, Galatians, 152; Bruce, Galatians, 168; Dunn, Galatians, 179; Hays, Faith of Jesus Christ, 181; William Hendriksen, Exposition of Galatians (NTC; Grand Rapids: Baker, 1968): 131; L. Ann Jervis, Galatians (Peabody: Hendrickson, 1999): 93.

37 The interpretation of the Abrahamic blessing as the Spirit is rejected by Kwon on the grounds that Paul does not make the equation explicit, and the lack of evidence elsewhere for identifying the Abrahamic promise with the Spirit (Kwon, Eschatology, 103-107).

38 See Thomas R. Schreiner, Galatians (ECNT; Grand Rapids: Zondervan, 2010): 219.

39 See Francis Watson, Paul and the Hermeneutics of Faith (London: T\&T Clark, 2004): 188-89. Further on, Paul is going to turn to another picture of blessing, that of sonship and inheritance, which also comes through faith and in Christ (3:25-26). 
to Gentiles. ${ }^{40}$ It would have been simpler and clearer for Paul to have

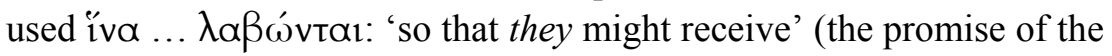
Spirit), or even the second-person plural, 'so that you might receive'. And if the second clause is simply defining the first-if the blessing of the Gentiles is the promise of the Spirit for 'us' - then Paul is somehow identifying himself as a Gentile- 'that we might receive the promise of the Spirit' - and this is highly unlikely, especially in view of the clear distinction he makes in 2:15-17 between Gentiles and those like himself who are Jews by nature. Or if the first-person plural $\lambda \alpha \dot{\beta} \omega \mu \varepsilon v$ ('we receive') is inclusive of Jewish and Gentile believers, in what sense could Paul's reception of the Spirit, along with that of other Jewish believers, be seen as the content of the blessing of the Gentiles?

I am not claiming that it is impossible that the clauses are coordinate in Galatians 3:14 or 4:5. However, in view of the evidence presented here it is certainly wrong to assume that they are. The assumption instead should be that they are not co-ordinate, and the burden of proof on those claiming that they are. Resistance to the notion that the two clauses in Galatians 3:14 are in sequence is due to the conceptual difficulty of holding that Jewish eschatological reception of the Spirit is somehow dependent on the blessing of the Gentiles. But if the clauses are in sequence, and if the second clause in Galatians 3:14 does indeed refer to Jews in particular, ${ }^{41}$ (and even if the 'we' of 3:14b includes both Jews and Gentiles), then Jewish reception of the Spirit-including Paul's own experience-is in some manner dependent on Gentiles receiving the blessing of Abraham. And this surprising idea is what Paul is in fact claiming. The blessing of the Gentiles is understood by Paul to be the eschatological and theological condition of the fulfilment of the promise of the Spirit to Israel. Christ redeemed Jews from the curse of the law, so that Gentiles would be blessed with the blessing of Abraham, and the result, in terms of eschatology, is that Jews receive the promise of the Spirit.

The third issue in 3:13-14 is the identification of the first-person plurals. Who are 'we' in this passage? There are several interpretive

40 A view held by some despite the first person plural verb, including Heikki Räisänen, who even claims that 'it would be strange, if the pronoun tacitly changed its reference in v. 14' (Räisänen, Paul and the Law, 19). Betz also seems to think this way (Betz, Galatians, 153). See Norman H. Young, 'Who's Cursed - And Why? (Galatians 3:10-14)', JBL 117 (1998): 79-92, esp. 91.

41 Wright, Climax of the Covenant, 143, 54. See also Witherington, Grace in Galatia, 240. 
options for the first person plural in Paul. One is the so-called epistolary plural, where Paul refers to himself in the plural, but this is not common. ${ }^{42}$ Second, Paul often uses the plural to refer to himself together with his companions or co-authors, usually fellow missionaries (Gal. 1:8; 2 Cor. 1:6-14), who are associated with the writing of the letter, and this is sometimes termed the 'exclusive we'. ${ }^{43}$ Third, he sometimes uses the first-person plural in an inclusive sense, encompassing himself (and co-authors) and his readers (1 Cor. 15:19; Phil. 3:3), or even all believers. ${ }^{44}$ Paul can move from an exclusive 'we' to an inclusive 'we', but there are normally contextual clues which signal the shift. ${ }^{45}$ Fourth, on a number of occasions, the referent includes Paul (and perhaps his co-authors) and a named or defined set of others, such as Paul and Apollos (1 Cor. 4:6), or Paul and the other apostles (1 Cor. 4:9). This defined set can sometimes include himself (with co-authors) and a subset of his readers. For example, in Romans 14:1 Paul includes himself and some of the Roman believers among the 'we who are strong'. There are also occasions where the defined set includes Paul with other Jews (Rom. 3:9; 7:6). ${ }^{46}$

Although it is not always obvious who the first-person plurals in Paul are referring to ${ }^{47}$ Galatians 2:15-17 should certainly be included

42 Richard Bauckham, 'Barnabas in Galatians', JSNT 2 (1979): 61-70, esp. 65. There is no evidence, however, for Bauckham's claim that the first-person plural in Gal. 1:8 includes Barnabas.

43 J. J. Kijne, 'We, Us and Our in I and II Corinthians', NovT 8 (1966): 171-79.

44 Even in these cases there is often a defined referent, such as in Rom. 8:12-17, where the first-person plural includes those who have the Spirit, by comparison to those who do not (Rom. 8:9).

45 For example, in 1 Cor. 1:22, if the first person plural is taken inclusively, so that God is 'the one who has also sealed us [all] and has given us [all] the guarantee of the Spirit in [all] our hearts', it is because in verse 21 the exclusive 'we' is specifically linked with the second person plural 'you': 'But the one who establishes us with you and anoints us is God'. Even here an exclusive sense for the first person plural could be maintained. In that case Paul is affirming the faithfulness of God (2 Cor. 1:18), and the certainty of what he has done in Paul and his companions for the extension of the gospel to the Corinthians.

46 See also Velma B. Pickens, 'Those Problem Pronouns: We, Us and Our in the New Testament', The Bible Translator 15 (1964): 88-92, and Kijne, 'We, Us and Our', who outline the problems facing translators in distinguishing between the referents of pronouns, especially when the receptor language and the source language do not treat exclusive and inclusive plurals the same way.

47 N. H. Young, 'Pronominal Shifts in Paul's Argument to the Galatians' in Ancient History in a Modern University, vol. 2, ed. T. W. Hillard et al. (Grand Rapids: Eerdmans, 1998): 205-215, esp. 208. Young argues for an inclusive 'we' in 3:13-14 and 4:3-6 without ever considering the real possibility that it is exclusive. The 'we' language is merely a matter of identification: "Though Paul uses "we" to identify with 
in this fourth category, because of 2:15 ('We who are Jews by nature'). The emphasis clearly is on believing Jews, Paul and his compatriots in Christ who were justified by faith. This passage sets the context for the next first-person plurals, which are found in 3:13, and likewise refer to Jews. For íva ... $\lambda \alpha ́ \beta \omega \mu \varepsilon v$ then in Galatians 3:14 to signify 'that we all might receive' one would expect there to be indicators to aid the reader to follow the sudden transition, but there is nothing in the context to suggest this. It is more likely that the referent of the firstperson plural here is the same as that found immediately prior, in 3:13: those who have been redeemed from the curse of the law. And after $3: 14$, the next first-person plurals are in 3:23-25, and these also reference Jewish believers, who were confined under the law until faith came. Therefore, even though commentators routinely assume an inclusive sense for this verb, ${ }^{48} \lambda \alpha ́ \beta \omega \mu \varepsilon v$ in 3:14 should indeed be understood in an exclusive sense. There is no basis to assume that the 'we' in 3:14 is inclusive.

There are at least two reasons why Paul would describe the blessing of the Jews in terms of the reception of the Spirit. First, Paul's appeal to the Galatians' experience of receiving the Spirit by faith, not by works of the law $(3: 2,5)$, is further legitimised, because Jews too, like Paul, receive the Spirit by faith (3:14). It is not always appreciated, in view of Paul's concern in the letter for the status of Gentiles in regard to the law and to the gospel, how much of the argument from 2:15 onwards is based on the soteriological status of Jews. Paul shares with his opponents the view that Gentiles and Jews are justified and receive the inheritance under the same conditions. What applies to Jews applies also to Gentiles (and vice versa). The question is, what conditions apply? The agitators are apparently holding that just as Jews must observe the law, so must Gentiles. Conversely, when Paul insists that he and other Jews 'also believed in Christ so as to be justified not by works of the law but through faith in Jesus Christ' $(2: 16)$, he does so because the same applies to his Gentile readers in Galatia. According to $3: 10-13$, those who are 'of the works of the law' are not justified before

the Galatians, his terminology reflects his Jewish heritage' (p. 214). This reading levels to nothing the topology of the letter.

48 Borse, An die Galater, 131; Fee, Presence, 394, Timothy George, Galatians (NAC, 30; Nashville: Broadman \& Holman, 1994): 243; H. Lietzmann, An die Galater (HNT, 10; Tübingen: J. C. B. Mohr [Paul Siebeck], 1971): 19; Lightfoot, Galatians, 140; Mußner, Galaterbrief, 235; Christopher D. Stanley, "Under a Curse": A Fresh Reading of Galatians 3.10-14', NTS 36 (1990): 481-511, esp. 508. 
God by that law. Instead, they must be redeemed from its curse. If therefore Jews cannot be justified by the law, neither can Gentiles. In regard to the Spirit, Paul reminds the Galatians that they received the Spirit by faith (3:1-5). So also here in 3:14 Paul insists that Jewish believers receive the Spirit in the same way-by faith.

The second likely reason for the mention of the Holy Spirit in specific relation to Jewish believers, both in $3: 14$ and 4:6, is that the promise of the Spirit is characteristic of Jewish expectations in regard to restoration and the new covenant. ${ }^{49}$ In 3:14 Paul focuses attention on the Spirit as the fulfilment of promise, to be received by faith. ${ }^{50}$ The emphasis is placed on the promise, by the forward placement of

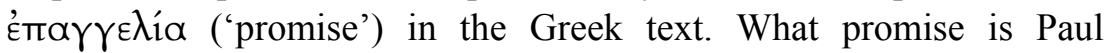
alluding to? Several key passages in the Old Testament promise the outpouring of the Spirit on a renewed and obedient Israel, ${ }^{51}$ and perhaps this idea is in the background. ${ }^{52}$ Richard Hays notes the similarities between Isaiah 44:3 (LXX) and Galatians 3:14, where the Spirit and the blessing are parallel terms in an eschatological promise: 'I will place my Spirit upon your seed and my blessing upon your children'. ${ }^{53}$ Morales comments, 'Paul's conclusion in 3, 14 presupposes a Jewish tradition, seen in Deutero-Isaiah, the Words of the Luminaries (4Q504), and the Testament of Judah, that present the gifts of the blessing and the Spirit as a sign of Israel's eschatological redemption'. ${ }^{54}$

If then Paul is arguing that Jewish and Gentile eschatological blessing is mutually necessary and interdependent, then one might expect to find the same idea appearing elsewhere in his writings. This is precisely what does happen, twice more in this same portion of Galatians.

49 See Fee, Presence, 395; Wright, Climax of the Covenant, 154.

50 Likewise, Paul argues in the next paragraph $(3: 15-19)$ that the eschatological inheritance comes by promise not law.

51 Isa. 32:15; 44:3; Ezek. 36:26-27; 37:14; 39:29; Joel 2:28-30; Zech. 12:10. See also Jub. 1:20-25; T. Levi 18:7-12.

52 All this also prepares Paul's readers for the ethical imperatives of chapter five, where he insists that 'if you are led by the Spirit you are not under the law' $(5: 18)$.

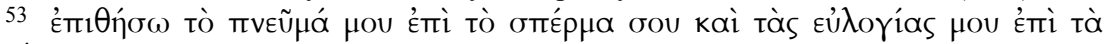
тékva oou. See Hays, Faith of Jesus Christ, 182.

54 Rodrigo J. Morales, 'The Words of the Luminaries, the Curse of the Law, and the Outpouring of the Spirit in Gal. 3,10-14', ZNW 100 (2009): 269-77, esp. 270. 


\section{Galatians 3:25-26}

In 3:23-25 Paul discusses the relationship of faith and the law. The law had a function as custodian ( $\pi \alpha 1 \delta \alpha \gamma \omega \gamma$ ós), a function which was temporally limited, confining Israel until the coming of faith. But 'now that faith has come', Paul says, 'we' that is, those same Jewish believers who have been redeemed from the curse of the law (3:13), 'are no longer under the custodian' (3:25). That the first person plurals in 3:23-25 refer to Jews should be obvious. The context is Paul's discussion of the purpose of the law as given through Moses (3:1-22). The law was given to Israel. According to 3:23 'we' were imprisoned 'under the law' (ن́riò vó $\mu \mathrm{ov}$ ), which was functioning as custodian. Israel, not the Gentiles, was under the law as custodian. With the coming of faith, that custodianship has come to an end. ${ }^{55}$

Verse 26 provides the basis for this remarkable claim. It is that 'you', that is, 'you Galatian Gentiles', are all sons of God, through faith and in Christ. To restate this: Paul is arguing that the liberty from the law that he and other Jewish believers have been granted is the result of the new status of sonship enjoyed by the Gentiles. To paraphrase a portion of 3:25-26: 'We [Jews] are no longer under the custodianship of the law, because you [Gentiles] are all sons of God'. This claim is similar to what Paul has already said in 3:14, that Jews have received the Spirit as a result of Gentiles receiving the blessing of Abraham. When 3:23-25 is held to refer to the Jews only, the ráp ('for') in 3:26 has been taken to have both 'explanatory and continuative functions'. ${ }^{56}$ Others treat the conjunction as transitional, seeing 3:26 as the start of a new thought. ${ }^{57}$ It has also been argued that the sonship of the Gentiles in 3:26 is not the condition but, as Betz puts it, 'the consequence of the preceding discussion of Jewish Christianity'. ${ }^{58}$ This would imply a similar thought to that expressed in 3:13-14a, in which Jewish redemption led to Gentile blessing. However, the possibility that ráp here is causal is strong, in the light

55 This does not mean that the law has no role at all after the coming of Christ. See Wilson, Curse of the Law, 39.

56 Longenecker, Galatians, 151. He finds the move to the second person plural in 3:26 'somewhat jarring'. For Dunn, 3:26 is both 'the basis of the argument just completed' and 'its conclusion' (Dunn, Galatians, 201).

57 G. Walter Hansen, Galatians (Downers Grove: Intervarsity, 1994): 110; Witherington, Grace in Galatia, 269.

58 Betz, Galatians, 185. 
of the parallels adduced in 3:14 and especially 4:6, where the sonship of the Galatians is causal to Jewish reception of the Spirit, and because a resultative use would be highly unusual. The ráp ('for') then in 3:26 is causal.

The ráp in 3:27 is explanatory. Paul is showing in 3:27-29 how the Galatians can all be sons of God. Because Christ is the Son of God (2:20), they are all sons. The Galatians have been 'baptised into Christ' and have 'put on Christ'. It is notable that here, as in most references to Christ as Son of God in Galatians, there is a sense of indwelling or incorporation. In 2:20, Paul insists that his life is no longer his own, for Christ lives in him and he lives only by faith in the Son of God. In 4:47, according to Paul, God not only sent his Son, but the Spirit of his Son 'into our hearts'.

The reason Paul emphasises the status of sonship conferred on the Gentiles, both here and in $4: 6$, is that as sons they can share in the eschatological inheritance $(3: 29,4: 7)$. Sons are heirs. ${ }^{59}$ It is likely that the agitators in Galatia insisted that the status of sonship was reserved for Jews. In the Old Testament, ${ }^{60}$ and in a range of early Jewish literature, ${ }^{61}$ the people of Israel are occasionally referred to as sons of God, or a similar designation. ${ }^{62}$ Now, in Christ the Son of God, this status is enjoyed by Gentiles, without the necessity of coming under the law. That is why Paul goes on to say, using what is possibly a fragment of earlier tradition, that there is neither Jew nor Greek (3:28). Being sons of God, and thus becoming heirs, is not a privilege belonging only to Jews. ${ }^{63}$

Some scholars make the pronouns of $3: 25$ and 26 functionally equivalent, so that the first-person plurals ('we') of 3:23-25, and the second person plural in 3:26 ('you') are inclusive of all believers, whether Jew or Gentile. ${ }^{64}$ The move to second-person plural is

59 See Brendan Byrne, 'Sons of God'-'Seed of Abraham': A Study of the Idea of the Sonship of God of All Christians in Paul against Its Jewish Background (Rome: Biblical Institute, 1979): 70.

60 Deut. 14:1-2; Isa. 1:2-4; 30:9; 43:6; 63:8; Jer. 3:22; Hos. 2:1. See also Exod. 4:2223; Hos. 11:1.

61 Sir. 36:17; Wis. 5:5; 3 Macc. 6:28; 4 Ezra 6:55-59; Pss. Sol. 17:26-27; Jub. 1:2225.

62 See the discussion in Byrne, Sons of God, 62-63.

63 Neither does this privilege depend on social or legal status: There is neither slave nor free, there is no 'male and female' (3:28).

64 'We should not read too much into Paul's noticeable transition from first person plural in v. 25 ("we") to second person plural ("you are") in v. 26' (George, Galatians, 
understood to be for particular application to the Galatians, ${ }^{65}$ to 'stress the place of Gentile believers', ${ }^{66}$ but the pronouns remain inclusive. Sometimes 3:26 has been seen as providing the proof or even the basis of the preceding argument, but on the assumption that those who are under the law in 3:23-25 are or at least include the Gentiles. ${ }^{67}$ However, Paul says in 3:23 that before faith came 'we' were

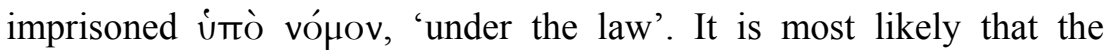
Galatians would interpret this phrase to refer to Jews, who had the law. And it is unlikely that Paul would choose to illustrate or indeed prove Jewish release from the confinement of the law by reference to the new status of the largely Gentile Galatians.

One important qualification ought to be noted: in 3:26 and 3:29 Paul emphasises that the Galatians are all sons of God, and 3:28 lists three pairs of opposites - Jew and Greek, slave and free, male and femalefor which that opposition is irrelevant in regard to being sons of Godand thus heirs. The most important pair for the argument of Galatians is the first one. Although the Galatian believers are largely Gentiles, there are likely to be some Jews among them, and so to a degree the statement in 3:25-26, 'We are no longer under the custodian, for you are all sons of God' anticipates the common sonship which belongs both to Jews, as in 4:5 (cf. Rom. 9:4), and to Gentiles (cf. Rom. 8:1417). Paul may be suggesting that Jewish release from the custodianship of the law, and reception of the Spirit was a result of this shared sonship.

273). F. F. Bruce comments, "Those addressed as "you" in v 26 are identical with those indicated by the inclusive "we" in vv 23-25' (Bruce, Galatians, 183). See also Duncan, Galatians, 122; Schlier, An die Galater, 166, 71; Jervis, Galatians, 101-105; Tolmie, Persuading the Galatians, 142.

65 Burton, Epistle to the Galatians, 202.

66 Hansen, Abraham in Galatians, 136.

67 Eckstein, Verheißung und Gesetz, 214; Hendriksen, Exposition of Galatians, 148; Mußner, Galaterbrief, 260. Kwon claims without offering evidence that 3:23-25 describes 'the Gentile believers' present relation vis-à-vis the law' (Yon-Gyong Kwon, Eschatology in Galatians: Rethinking Paul's Response to the Crisis in Galatia [WUNT, 183/2; Tübingen: Mohr Siebeck, 2004]: 87). Matera resorts to suggesting that the 'we' in 3:23 indicates the Jews, but the 'we' in 3:25 indicates simply 'believers' (Frank J. Matera, Galatians, ed. Daniel J. Harrington (Sacra Pagina, 9; Collegeville: The Liturgical Press, 1992): 140-41). 


\section{Galatians 4:4-7}

The parallels between this passage and 3:13-14 have already been mentioned above. Paul has already told the Galatians that they are heirs of Abraham (3:29). Using an illustration taken from contemporary life (4:1-2), he shows that the Jews themselves (1) were in effective slavery under the law (4:3); (2) have only received their adoption because God sent his Son to redeem those under the law (i.e. the Jews, 4:5);68 and (3) have only received the Spirit because the Gentiles themselves were Sons of God (4:6). Therefore the Gentile Galatians, far from gaining status and inheritance by coming under and practising the law, even as they are now beginning to do in terms of the calendar (4:10) ${ }^{69}$ would instead be reverting from their current status of heirs to that of slaves (4:7-11).

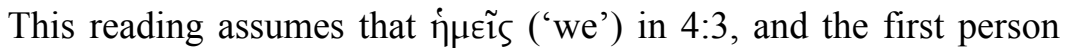
plural ómо $\lambda \alpha ́ \beta \omega \mu \varepsilon v$ ('we receive') in 4:5 are exclusive, referring to Jews. In the case of $4: 3$, this is not an unusual interpretation, ${ }^{70}$ because of $4: 4$ which describes a temporal contrast between the state of

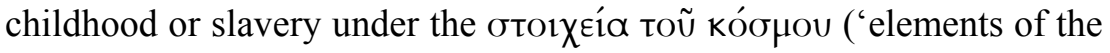
world'), and the subsequent redemption of these same people. The situation described in verse 3 with the mixed metaphors of slavery and childhood is resolved through the sending of the Son of God to those redeemed under the law (v. 4), so that verse 5 describes a divine reversal. Those under the law (i.e. Jews) are redeemed, and they

68 Betz, Galatians, 208; Duncan, Galatians, 129; Hong, The Law in Galatians, 159; Longenecker, Galatians, 172; Matera, Galatians, 150. The idea that the Gentiles are secondarily included here (Hendriksen, Exposition of Galatians, 160; Lightfoot, Galatians, 168) is only possible by arguing that úmò vó importing ideas from Rom. 2:14-15 (Cf. Burton, Epistle to the Galatians, 219).

69 According to Dunn, 'Paul clearly has particularly Jewish festivals in mind' (James D. G. Dunn, 'Echoes of Intra-Jewish Polemic in Paul's Letter to the Galatians', JBL 112 (1993): 459-77, esp. 470). Martin argues that the list in 4:10 indicates pagan calendric observances (Troy Martin, 'Time-Keeping Schemes in Gal. 4.10 and Col. 2.16', NTS 42 (1996): 105-119), but this seems unlikely given the lack of evidence in the rest of the letter for a return to paganism on the part of the Galatian believers. The usual explanation for the list not including distinctively Jewish terms is that Paul was reinforcing his point (4:8-9) that for his Gentile converts to be circumcised and follow the law of Moses would be the equivalent of returning to paganism (Mußner, Galaterbrief, 302-303). See also Longenecker, Triumph, 30 n. 10.

70 Linda L. Belleville, "Under Law": Structural Analysis and the Pauline Concept of Law in Galatians 3:21-4:11', JSNT 26 (1986): 53-78, esp. 68; Bruce, Galatians, 193; Hansen, Galatians, 116; D. W. B. Robinson, 'The Distinction between Jewish and Gentile Believers in Galatians', Australian Biblical Review 8 (1965): 29-48, esp. 37. 
(including Paul, so now designated as 'we') receive the adoption

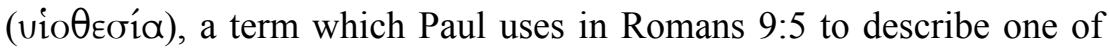
the privileges of Israel.

The two iv $\alpha$ clauses in verse 5 are probably again sequential rather than parallel. ${ }^{71}$ The first clause promises redemption, the second adoption. Redemption or liberation from slavery under the law is the presupposition or condition of the adoption. The imagery may allude to the fulfilment of the covenant promises in the Exodus (Exod. 6:1-8), or to its reinterpretation in later prayer (2 Sam. 2:23-24) and prophecy (Isa. 43:1-14). But the notion of being liberated from slavery in order to be adopted as a son and heir also had precedent in Roman law and practice. ${ }^{72}$ It was even possible by a single legal process for someone to be emancipated from slavery to one person in order to be adopted as a son and heir by another. ${ }^{73}$ But even if the two clauses are taken in parallel, which is grammatically unlikely (see above on 3:14), there is no sufficient reason to follow the majority of commentators in holding the second clause in 4:5 to refer to an inclusive 'we', both Jews and Gentiles, ${ }^{74}$ even though some may find this view theologically attractive, and despite the similar language in Romans 8:15-16, which is inclusive. It is most natural in context to read 'we' in Galatians 4:5b as a reference to Jews, those who were under the law. ${ }^{75}$ The obvious antecedent of the first person plural in 4:5b (and 6b) is the first person plural in verse 3 , especially in view of the sudden change to and contrast with the second person plural in verse $6 \mathrm{a}$. Paul is talking about Jews from 4:1 to $4: 5$, in a very similar manner to what he has said in 3:23-26 concerning the law as the custodian of Israel, but expressed with a different set of metaphors.

71 Betz, Galatians, 208.

72 Alan Watson, Roman Slave Law (Baltimore: Johns Hopkins University Press, 1987): 27.

73 David Johnston, Roman Law in Context (Key Themes in Ancient History, Cambridge: Cambridge University Press, 1999): 33

74 Betz, Galatians, 208; Lightfoot, Galatians, 169; Mußner, Galaterbrief, 270-71; Schlier, An die Galater, 197; though not Longenecker, Galatians, 172.

75 'It seems clear from the context that 4:1-5 refers specifically to pre-Christian, Jewish life under the law' (Linda L. Belleville, "'Under Law": Structural Analysis and the Pauline Concept of Law in Galatians 3:21-4:11', JSNT 26 (1986): 53-78, 68). See also Nancy L. Calvert, 'Abraham and Idolatry: Paul's Comparison of Obedience to the Law with Idolatry in Galatians 4.1-10' in Paul and the Scriptures of Israel, ed. Craig A. Evans and James A. Sanders (Sheffield: JSOT Press, 1993): 222-37, esp. 224. 
If that is the case, the apparently awkward shifts, ${ }^{76}$ from first person in verse 5 to second person in verse 6 and then back again, are necessary because Paul is talking about different groups of people. The mild adversative $\delta \varepsilon$ aids the distinction. ${ }^{77}$ While in some places in Paul sudden pronominal shifts are less significant, or their meaning simply unclear, ${ }^{78}$ ignoring the shifts in person and number in this passage causes a loss of clarity and obscures the flow of thought. The öt1 ('because') in 4:6 is causal. ${ }^{79}$ Paul is claiming that God sent the Spirit of his Son into the hearts of Jewish believers, including Paul, because the Gentiles, including the Galatian believers, are now sons (through Christ), as he has already established in 3:29.

The tendency again is for commentators to take unquestioningly the first person plural here ( $\dot{\eta} \mu \tilde{\omega} v)$ as inclusive ('all our hearts'), perhaps under the influence of Romans $8: 15 .{ }^{80}$ But there is no contextual reason that this must be the case, and this is especially so if the preceding analysis has been correct. This verse can be seen in a different light. It is the third witness in the letter to Paul's perception that eschatological blessing of Jews was dependent, theologically at least, on the blessing of the Gentiles. ${ }^{81}$

\section{Interdependence in What Sense?}

Paul does not indicate directly where he derived his idea from, nor exactly how the interdependence he implies functions. However, the following remarks may help clarify the background and use of this idea. That the salvation of Gentiles would result from the salvation of

\footnotetext{
76 Longenecker, Galatians, 173.
}

77 Commentators tend to merge all the pronouns into meaninglessness, or let them pass without comment (R. Alan Cole, The Epistle of Paul to the Galatians: An Introduction and Commentary, ed. R. V. G. Tasker [TNTC; Grand Rapids: Eerdmans, 1965]: 116; Mußner, Galaterbrief, 274-75; Schlier, An die Galater, 197).

78 See Young, 'Pronominal Shifts', 208.

79 Betz, Galatians, 209. Some older commentators take ǒtı here as demonstrative, 'as a proof that you really are sons' (Ellicott, Epistle to the Galatians, 95), because of the perceived difficulty otherwise of moving from 4:5 to 4:7.

80 Betz, Galatians, 210; Fee, Presence, 404-405. That there is an apparent difficulty is indicated by the presence of the second person plural $\dot{v} \mu \tilde{\omega} v$ in the manuscript tradition $\left(\mathrm{D}^{2} \Psi 33 \mathfrak{R}\right)$.

81 If this reading is correct, arguments over Gal. 4:4-6 concerning the order of salvation (sonship before Spirit?) become moot. It is also less necessary to posit prePauline tradition behind vv. 4-5 (see Longenecker, Galatians, 170) to explain the apparent difficulties. 
Israel is an idea not really under dispute. There are numerous passages in Old Testament and Second Temple Jewish literature which testify to this idea. ${ }^{82}$ In some of these passages the Gentiles turn to God when they see his saving acts on behalf of Israel-acts which include the judgement of Gentile nations (Ps. 67; 98:1-3; 102:13-16; 117; Isa. 45:14-25; 52:8-10; 60:1-3; Jer. 16:14-19; Ezek. 37:21-28). In some the Gentiles come in 'pilgrimage' to a restored Israel (Isa. 2:2-4; 55:3-5; 56:6-8; Jer. 3:14-17; Mic. 4:1-3; Tob. 13:9-11). In some passages it is not even obvious that the salvation of Israel always precedes that of the Gentiles, such as where a messianic figure comes to rule Israel and the nations (Pss. Sol. 17:21-35; Tg. Onq. Gen. 49:10; 1 Enoch 48:4). In Isaiah 11:10-11 (LXX), the restoration of Israel follows the Gentiles' trust in the root of Jesse, the one who is raised to rule over them. ${ }^{83}$ In Isaiah 59:19-20, the fear of the Lord in the nations precedes or at least coincides with the coming of a deliverer to Zion. The point is, there is such a close association of the restoration of Israel and the salvation of the Gentiles in many texts that the latter can be seen as an intrinsic part of the former - or vice versa. One would not happen without the other.

The question is, of course, whether Paul also saw it that way. In Galatians 3:6-9 he has interpreted his combined quote of Genesis 12:3 and 18:8, 'in you all the Gentiles will be blessed' in the light of Genesis 15:6: 'Abraham believed God and it was reckoned to him as righteousness'. The blessing of Abraham comes through sharing the faith of Abraham. Paul seems to understand the Abrahamic blessing of Genesis $12: 1-3$ as a unity which would find ultimate fulfilment in Christ, in such a way that the blessing of Israel (Gen. 12:2) and the families of the earth (Gen. 12:3; 18:8) are equally necessary parts of that fulfilment. They would not happen independently but only as parts of the same divine plan, and through the one seed Christ (Gal. 3:16), the Son of God. The promised blessing of Israel awaited the coming of the Messiah, the coming of faith (Gal. 3:23-24), and the blessing of the Gentiles.

Thus far the discussion has focused rather narrowly on the argument of Galatians. This reading of Galatians may also be echoed in Romans. I have suggested previously that Paul, drawing upon passages in the Psalms and Isaiah (especially Ps. 98:2 [LXX 97:2]), celebrates the

\footnotetext{
82 See above, note 1.

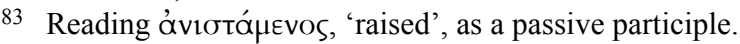


growing faith of the Gentiles as evidence that the righteousness of God is being revealed in the gospel, the gospel which means salvation for both Jews and Gentiles (Rom. 1:16-17). ${ }^{84}$ It is not far from seeing the faith of the Gentiles as a key sign of the coming of eschatological salvation to Israel, to understanding it as a necessary corollary of that salvation, even though the gospel was first preached to Jews.

There is other evidence too in Romans of some sense of the interdependent salvation of Jews and Gentiles. On the one hand, the Gentiles share in Israel's salvation. The gospel is for the Jew first, and also the Greek (1:16). Christ came to confirm the promises to Israel's patriarchs, and so that the Gentiles, who have not previously given God his deserved glory (1:21), should now glorify him (15:8-9). The Gentiles rejoice in Israel's salvation (15:10-11), and hope in Israel's Messiah (15:12; cf. Isa. 11:10 LXX). The Gentiles have a debt because they share in the spiritual blessings ( $\pi v \varepsilon v \mu \alpha \tau \imath k \alpha$ ) of the Jewish believers (15:27). On the other hand, Paul is a debtor to Greeks and barbarians, and must therefore proclaim the gospel to them (Rom. 1:14). In Romans 11:11-27 Jews and Gentiles are made interdependent in terms of salvation history, though with some variation from the pattern in Galatians. Even though for the present it is Israel's trespass, not its blessing, that has resulted in salvation for the Gentiles, nevertheless even in this there is interdependence, and there is still the remnant (Rom. 11:1-6). Ultimately, the salvation of Israel will mean life from the dead for the world (Rom. 11:15). Paul insists that Jewish blessing is indeed dependent on Gentile inclusion: 'Salvation has come to the Gentiles to make Israel jealous' (Rom. 11:11). In the end, when 'the fullness of the Gentiles come in', then 'all Israel will be saved' (Rom. 11:25-26).

All this suggests the possibility that in Paul's thinking the blessing of the Gentiles was not only a sure consequence but a necessary sign and corollary of the redemption of Israel in Christ. Given also Paul's insistence on the unity and equality of Jews and Gentiles in Christ, and in the new creation (Gal. 3:28, 6:15) and on their justification on the same basis of faith (Gal. 2:15-16), and given the evidence adduced above from three key passages in Galatians, it seems right to posit, in Galatians at least, not a missiological cause and effect but a theological or rather an eschatological dependence between Jews and Gentiles.

84 Isa. 51:4-8; 52:10; 56:1-8. See Taylor, 'From Faith to Faith', esp. 346-48. 
Paul understands that in the divine plan neither group was going to experience deliverance from 'this present evil age' (Gal. 1:4) without the other.

\section{Conclusions}

The conjunction œ̋ $\sigma \tau \varepsilon$ ('as a result') in Galatians 4:7 indicates a conclusion, and this is expressed with the second person again, confirming what was said in 3:29. ${ }^{85}$ The Galatian believers are indeed heirs. But it is also the conclusion to the whole argument from 3:15 onwards concerning promise and inheritance, and possibly from 3:6 onwards. For in 3:1-5 and 4:8-10 Paul is registering his complaint at the Galatians' foolishness. They are ending with the flesh (3:3). They

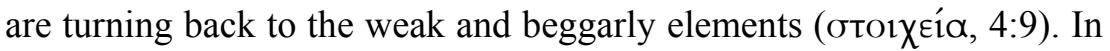
between, he explains further why they need not come under the law, in an argument based on the idea of the inheritance of the blessing or promise of Abraham. The agitators' false gospel has made Gentile blessing secondary and subsidiary to Jewish eschatological status. Therefore the new converts must adopt and submit to the law, especially circumcision, to be certain of their status as inheritors of the promises to Abraham.

Paul counters this by showing how Jew and Gentile are equal, using three key arguments, of which the third has been the focus of this article. One is that even Jewish believers only receive justification, the inheritance, the promises, adoption and the Spirit by redemption from slavery, by being set free from the curse and power of the law, and all this only by faith and in Christ, and not through works of the law. By analogy, it is surely no different for the Gentiles.

The second is related. Gentile Galatian believers have already received the Spirit $(3: 1-5)$, already they have become heirs by faith; already they are sons of God (4:7). To adopt the law would be to enter the servitude Israel was under before faith came, and in effect to return to the same kind of slavery they were in before they believed (4:9). That is why Paul's request in 4:12, which some have seen as key to the

85 'As a result you are no longer a slave, but a son, and if a son, then also an heir through God'. The use of the singular है ('you are') can be explained as corresponding to the singular 'heir' ( $\mathrm{k} \lambda$ проvóno $)$ in $4: 1$. It also perhaps serves to encourage the Galatians to apply Paul's teaching individually. 
whole letter, ${ }^{86}$ makes sense: 'Become as I am, because I also have become as you are'.

The third argument is the eschatological interdependence of Jew and Gentile: one will not be blessed without the other. Gentiles are blessed in Christ because Jews are redeemed by Christ. Jews are redeemed, and set free from the law, because Gentiles have become sons of God. The emphasis is particularly on the eschatological necessity for Gentiles to be blessed, to become sons of God, in order that Jews might be released from confinement under the law and receive the promised Holy Spirit. Thus Paul turns around the message of the agitators. The justification of Gentiles in Christ is not subordinate to the justification of Jews, and therefore there is no necessity for Gentile converts to Christ to become Jewish proselytes as well.

86 Hansen, Abraham in Galatians, 44-48; Longenecker, Galatians, 184. 